\title{
Pengaruh Waktu Fermentasi Teh Kombucha Kadar 75\% terhadap Profil Lipid Tikus Putih
}

\section{The Influence of Tea Kombucha Fermentation Time on Level 75\% To Lipid Profile}

\author{
Sri Isdadiyanto*, Silvana Tana \\ Departemen Biologi, Fakultas Sains dan Matematika, Universitas Diponegoro \\ Jl. Prof. Soedarto, SH, Tembalang, Semarang \\ *Email: isdadiyanto@yahoo.com
}

Diterima 1 Juli 2016 / Disetujui 18 Agustus 2016

\begin{abstract}
ABSTRAK
Tujuan penelitian ini untuk mengetahui pengaruh pemberian teh kombucha kadar $75 \%$ sebagai drinking water dengan variasi waktu fermentasi. Penelitian ini menggunakan Tikus putih (Rattus norvegicus) jantan sebanyak 16 ekor umur 2 bulan, dengan perlakuan Teh kombucha yang difermentasi selama 6,9 dan 12 hari pada suhu $25^{\circ} \mathrm{C}$ per oral. Penelitian ini menggunakan Rancangan Acak Lengkap dengan 4 perlakuan (selama 28 hari) dan 4 ulangan, yaitu : $\mathrm{P} 0=$ kontrol, tanpa tambahan teh kombucha, $\mathrm{P} 1=$ air minum $+1,8 \mathrm{ml}$ teh kombucha pagi dan sore fermentasi 6 hari, $\mathrm{P} 2=$ air minum $+1,8 \mathrm{ml}$ teh kombucha pagi dan sore fermentasi 9 hari, P3 = air minum $+1,8 \mathrm{ml}$ teh kombucha pagi dan sore fermentasi 12 hari. Variabel yang diukur adalah kadar kolesterol, HDL dan LDL. Data yang diperoleh dianalisis menggunakan ANOVA yang dilanjutkan dengan Uji Duncan dengan taraf kepercayaan 95\% dengan menggunakan perangkat lunak SPSS 10,0. Hasil penelitian menunjukkan bahwa pemberian teh kombucha dapat menaikkan kadar HDL, menurunkan kadar kolesterol dan LDL serum darah tikus putih (Rattus norvegicus).
\end{abstract}

Kata kunci: Rattus norvegicus, teh kombucha kadar 75\%, kolesterol, HDL, LDL

\begin{abstract}
The objective of this study was to analyze the influences of $75 \%$ kombucha tea level on lipid profile in rats. Sixteen male Rattus norvegicus rats, 2 months of age were used as experimental animals, with treatment kombucha tea that has been fermented for 6,9 and 12 days at the temperature of $25^{\circ} \mathrm{C}$ per oral. The research design used to a completely randomized with 4 treatment (for 4 weeks) and 4 replications, namely: $P 0=$ control, without of kombucha tea, $P 1=$ water $+1,8 \mathrm{ml}$ kombucha tea that has been fermented for 6 days in the morning and afternoon, $P 2=$ water $+1,8 \mathrm{ml}$ kombucha tea that has been fermented for 9 days in morning and afternoon, $P 3=$ water $+1,8 \mathrm{ml}$ kombucha tea that has been fermented for 12 days in morning and afternoon. Variables measured were cholesterol, LDL and HDL level. Data were analyzed with ANOVA followed by Duncan test at 95\% confidence level were performed using SPSS version 10,0. The result showed that kombucha tea increased HDL level, but decreased total cholesterol level and LDL level in rats.
\end{abstract}

Keywords: Rattus norvegicus, $75 \%$ kombucha tea level, cholesterol, $H D L, L D L$

\section{PENDAHULUAN}

Teh kombucha adalah minuman yang murah dan mudah dibuat oleh masyarakat di Indonesia yang memiliki beberapa khasiat bagi tubuh antara lain dapat mempengaruhi tubuh secara menyeluruh dengan menstabilkan metabolisme tubuh. Melalui peningkatan metabolisme, penimbunan lemak di dalam tubuh yang terlalu banyak bisa dihindari. Teh kombucha mengandung senyawa-senyawa kimia yaitu vitamin B (tiamin / B1, riboflavin / B2, niasin / B3, piridoksin / B6, sianokobalanin / B12), vitamin C dan polyfenol. Teh kombucha diduga berperan dalam metabolisme lemak sehingga mempunyai potensi untuk menurunkan kadar kolesterol jahat, yakni LDL dan trigliserida, serta meningkatkan kadar HDL, hingga bisa mengurangi risiko 
terhadap penyakit pembuluh darah dan jantung coroner . Katekin merupakan salah satu unsur dari polyfenol dapat mencegah tekanan darah tinggi, mengurangi penimbunan kolesterol dalam darah, mempercepat pembuangan kolesterol melalui feces, menangkal radikal bebas, serta dapat mengurangi risiko penyakit kardiovaskuler (Naland, 2008).

Hasil penelitian yang telah dilakukan oleh

Purwaning (2010) dan Rahayu (2005) menggunakan teh kombucha terhadap tikus putih menunjukkan penurunan kadar kolesterol. Hal ini didukung pula oleh Winarni dkk. (2010) menyatakan bahwa teh kombucha mempunyai kecenderungan menurunkan kadar kolesterol darah meskipun secara statistik tidak terbukti dengan obyek perlakuan terhadap mahasiswa Fakultas Kedokteran Universitas Sebelas Maret Surakarta. Adriani et al. (2011) yang menggunakan itik sebagai hewan percobaan menyatakan bahwa teh kombucha dapat menurunkan kadar kolesterol total darah, selain itu juga mengurangi kolesterol LDL dan menaikkan kolesterol HDL sesudah mengkonsumsi teh kombucha selama 4 minggu. Hasil penelitian Pratiwi et al. (2012) menyatakan pembuatan teh kombucha mempunyai kandungan alkohol tertinggi pada fermentasi hari ke-12 dan menurun pada hari ke-16, kandungan vitamin $\mathrm{C}$ menurun pada hari ke-4 dan meningkat kembali hingga hari ke-16. Asam total terus meningkat sampai hari ke-16, nilai $\mathrm{pH}$ dan gula total semakin menurun pada hari ke-16.

Kolesterol di dalam darah beredar tidak dalam keadaan bebas, akan tetapi berada dalam partikel - partikel lipoprotein. Lipoprotein terdiri atas 4 jenis yaitu kilomikron, VLDL, low density lipoprotein (LDL), dan high density lipoprotein (HDL) (Devlin, 1992; Mayes \& Botham, 2003 ${ }^{\mathrm{a}}$ ). Satu atau lebih apoprotein (protein dan polipeptida) ditemukan pada setiap lipoprotein. Apoprotein utama HDL adalah apoprotein A, apoprotein utama LDL adalah apoprotein B, yang juga ditemukan pada VLDL dan kilomikron. Fungsi apoprotein A sebagai reseptor HDL dan apoprotein B sebagai reseptor LDL. Aterosklerosis berkaitan dengan rasio yang tinggi LDL:HDL atau rasio tinggi apoprotein $\mathrm{B}: \mathrm{A}$ dalam plasma (Mayes
\& Botham, 2003 ${ }^{\mathrm{b}}$ ). Apoprotein B merupakan protein utama dalam partikel lipoprotein aterogenik dan terutama terdapat dalam partikel LDL. Setiap partikel LDL mengandung satu molekul apo B, dengan demikian konsentrasi apoprotein B mencerminkan jumlah partikel LDL dalam tubuh (Haksa, 2010).

Aterosklerosis berhubungan dengan peningkatan LDL. Pengaruh peningkatan kadar LDL akan diikuti akumulasi ester kolesterol dalam makrofag sehingga kemudian makrofag disebut sebagai sel busa. Kadar LDL yang tinggi menyebabkan tingginya kadar LDL intimal. Selanjutnya LDL intimal akan mengalami oksidasi dan menarik monosit dari sirkulasi darah serta berubah secara fenotipik menjadi makrofag. Peningkatan LDL teroksidasi pada dinding arteri disertai dengan terbentuknya sel busa, akan berkembang menjadi lempeng lemak (Bankson et al., 1993).

Berdasarkan latar belakang di atas, perlu dilakukan penelitian untuk mendapatkan bukti dan informasi tentang profil lipid tikus putih setelah pemberian teh kombucha kadar $75 \%$ sebagai drinking water dengan variasi waktu fermentasi.

\section{METODE PENELITIAN}

Penelitian dilakukan di Laboratorium Biologi Struktur dan Fungsi Hewan, Departemen Biologi Fakultas Sains dan Matematika Universitas Diponegoro Semarang, pada bulan Mei sampai Juli 2015. Menggunakan Tikus putih (Rattus norvegicus) jantan sebanyak 16 ekor umur 2 bulan, sedang untuk bahan perlakuan yaitu Teh kombucha kadar $75 \%$ yang difermentasi selama 6 , 9 dan 12 hari pada suhu $25^{\circ} \mathrm{C}$ per oral dengan spuit injeksi ujung berkanul. Adapun alat-alat yang digunakan yaitu 20 kandang individu yang dilengkapi dengan tempat minum dan pakan, gelas ukur, timbangan digital, disetting set.

Penelitian ini menggunakan Rancangan Acak Lengkap dengan 4 perlakuan dan 4 ulangan yaitu : $\mathrm{P} 0=$ kontrol, tanpa tambahan teh kombucha, $\mathrm{P} 1=$ air minum $+1,8 \mathrm{ml}$ teh kombucha kadar $75 \%$ pagi dan sore fermentasi 6 hari, P2 = air minum $+1,8 \mathrm{ml}$ teh kombucha kadar $75 \%$ pagi 
dan sore fermentasi 9 hari, P3 = air minum $+1,8$ $\mathrm{ml}$ teh kombucha kadar $75 \%$ pagi dan sore fermentasi 12 hari. Pakan dan minum diberikan secara ad libitum .

Variabel yang diukur adalah kadar kolesterol, HDL dan LDL. Data yang diperoleh dianalisis dengan ANOVA, berdasarkan Rancangan Acak Lengkap (RAL) pada taraf kepercayaan $95 \%(\alpha=0,05)$. Analisis keseluruhan menggunakan perangkat lunak software SPSS 10,0 (Mattjik dan Sumertajaya, 2006).

\section{HASIL DAN PEMBAHASAN}

Data hasil analisis penelitian terhadap ratarata kolesterol, HDL dan LDL pada Tikus putih (Rattus norvegicus) jantan setelah pemberian Teh kombucha kadar $75 \%$ yang difermentasi selama 6 , 9 dan 12 hari disajikan pada Tabel 1.

Tabel 1. Hasil analisis rata-rata kadar kolesterol, HDL dan LDL pada Tikus putih (Rattus norvegicus) jantan setelah pemberian Teh kombucha kadar 75\% yang difermentasi selama 6, 9 dan 12 hari

\begin{tabular}{cccc}
\hline & Cholesterol & HDL & LDL \\
\hline P0 & $132.16^{\mathrm{a}} \pm 2.23$ & $82.16^{\mathrm{c}} \pm 1.04$ & $133.86^{\mathrm{a}} \pm 2.65$ \\
P1 & $109.58^{\mathrm{b}} \pm 1.28$ & $91.32^{\mathrm{b}} \pm 1.98$ & $121.86^{\mathrm{b}} \pm 2.72$ \\
P2 & $103.30^{\mathrm{c}} \pm 3.00$ & $92.22^{\mathrm{b}} \pm 1.34$ & $118.28^{\mathrm{c}} \pm 1.36$ \\
P3 & $98.69^{\mathrm{d}} \pm 2.00$ & $95.18^{\mathrm{a}} \pm 1.80$ & $115.61^{\mathrm{c}} \pm 1.33$ \\
\hline
\end{tabular}

Keterangan :

Angka dengan superskrip yang berbeda pada baris yang sama menunjukkan perbedaan yang nyata antar perlakuan. P0 = kontrol, tanpa tambahan teh kombucha kadar 75\%, P1 = air minum $+1,8 \mathrm{ml}$ teh kombucha kadar $75 \%$ pagi dan sore fermentasi 6 hari, $\mathrm{P} 2=$ air minum $+1,8 \mathrm{ml}$ teh kombucha kadar $75 \%$ pagi dan sore fermentasi 9 hari, $\mathrm{P} 3=$ air minum 1,8 $\mathrm{ml}$ teh kombucha kadar $75 \%$ pagi dan sore fermentasi 12 hari.

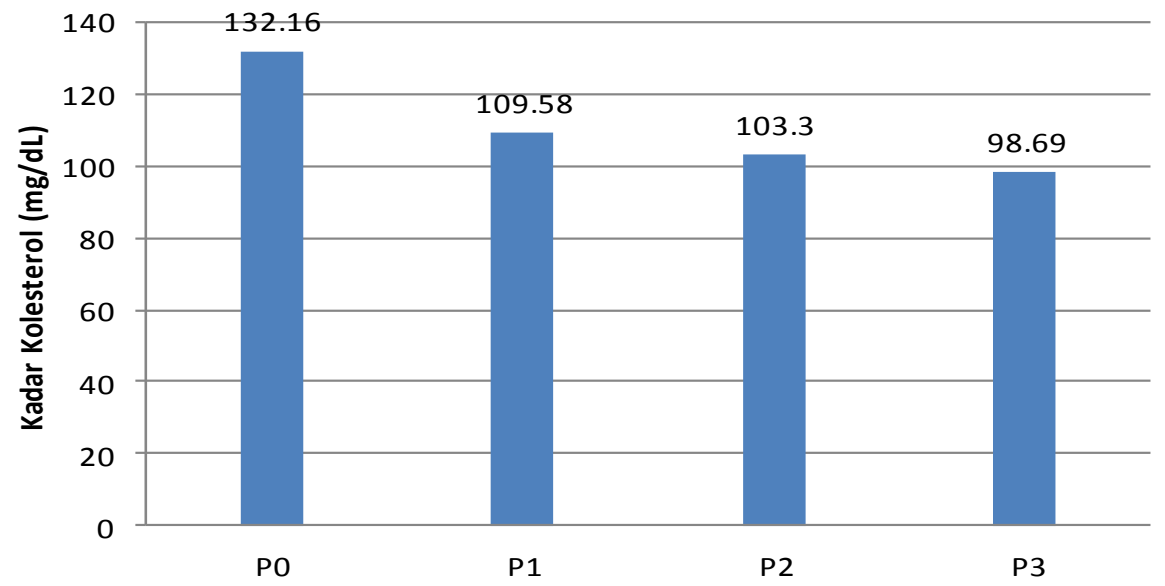

Gambar 1. Histogram rata-rata kadar kolesterol (mg/dL) pada setiap perlakuan

\section{Keterangan :}

$\mathrm{P} 0=$ kontrol, tanpa tambahan teh kombucha kadar 75\%, P1 = air minum $+1,8 \mathrm{ml}$ teh kombucha kadar $75 \%$ pagi dan sore fermentasi 6 hari, $\mathrm{P} 2$ = air minum 1,8 $\mathrm{ml}$ teh kombucha kadar $75 \%$ pagi dan sore fermentasi 9 hari, $\mathrm{P} 3=$ air minum $1,8 \mathrm{ml}$ teh kombucha kadar $75 \%$ pagi dan sore fermentasi 12 hari.

Semakin lama fermentasi teh kombucha yang diberikan, semakin menurun kadar kolesterol pada tikus putih (Rattus norvegicus) dibandingkan dengan kontrol seperti tampak pada gambar 1. Metabolit yang terkandung dalam teh kombucha antara lain adalah Niasin atau vitamin (vitamin B3) yang juga disebut asam nikotinat, bekerja di dalam tubuh sebagai koenzim dalam bentuk Nikotinamida Adenin Dinukleotida (NAD) dan Nikotinamida Adenin Dinukleotida Fosfat 
(NADP). Koenzim ini adalah akseptor hidrogen berikatan dengan atom hidrogen dalam bentuk koenzim dehidrogenase yang merupakan katalis pada reaksi oksidasi reduksi. $\mathrm{NAD}^{+}$berfungsi sebagai koenzim dalam reaksi oksidasi alkohol dalam reaksi berikut : $\mathrm{CH}_{3} \mathrm{CH}_{2} \mathrm{OH}+\mathrm{NAD}^{+} \leftrightarrow$ $\mathrm{CH}_{3} \mathrm{CHO}+\mathrm{NADH}+\mathrm{H}^{+}$. Reaksi ini akan menghasilkan ion $\mathrm{H}^{+}$, maka akan berjalan baik pada $\mathrm{pH}$ rendah (suasana asam) (Poedjiadi, 1994). Nikotinamid merupakan komponen dari hampir semua zat-zat pembawa elektron dalam sel hidup (NAD+/NADH; NADP+/NADPH) dan berfungsi dalam banyak lintasan metabolisme terutama dalam: (1) glikolisis anaerob, (2) oksidatif fosforilasi siklus kreb dan (3) sintesis $\beta$-oksidasi asam lemak (Linder, 1992).

Penurunan kadar kolesterol oleh niasin dapat dilakukan dengan cara menghambat perubahan lemak jaringan, mengurangi pengambilan asam lemak bebas oleh hati dan meningkatkan pengeluaran kolesterol oleh hepar melalui getah empedu. Niasin berperan dalam merangsang pembentukan hormon prostaglandin $\mathrm{I}_{2}$ yaitu hormon yang mencegah penggumpaklan (agregasi) trombosit sehingga dapat memperkecil risiko aterosklerosis (Rahayu, 2005).

Hasil penelitian ini menunjukkan bahwa hubungan LDL dengan kolesterol total adalah berbanding lurus. Hal tersebut terjadi karena $45 \%$ kolesterol berada dalam bentuk LDL (Mathews \& Van Holde,1991). Artinya jika kolesterol total turun maka LDL juga turun. Hal ini terjadi karena terhambatnya atau terganggunya proses absorbsi kolesterol di usus halus dan meningkatnya ekskresi asam empedu melalui feses. Asam empedu merupakan hasil metabolisme akhir dari kolesterol. Dengan tingginya ekskresi asam empedu maka akan semakin banyak kolesterol yang diubah menjadi asam empedu untuk mengelmusikan lemak, sehingga kolesterol total dan LDL serum menurun.

Mekanisme naiknya kadar HDL karena pengaruh pemberian Teh kombucha kemungkinan disebabkan oleh pengikatan asam empedu oleh metabolit (yang terkandung dalam teh kombucha) di dalam usus halus yang menyebabkan meningkatnya ekskresi asam empedu fekal, sehingga terjadi penurunan absorbsi lemak dan kolesterol, hal ini mengakibatkan kolesterol dalam hati rendah sehingga kolesterol untuk memproduksi asam empedu kurang. Kondisi ini merangsang terjadinya sintesis HDL dalam hati untuk memenuhi kekurangan kolesterol tersebut. Akibatnya LDL serum lebih rendah daripada HDL serum.

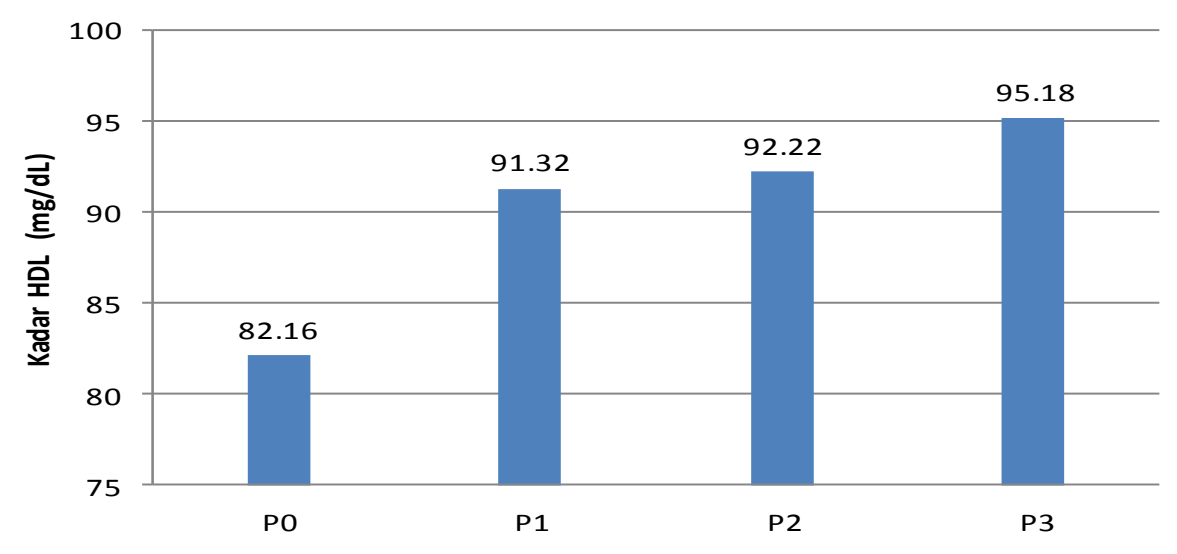

Gambar 2. Histogram rata-rata HDL (mg/dL) pada setiap perlakuan

Keterangan :

$\mathrm{P} 0=$ kontrol, tanpa tambahan teh kombucha kadar 75\%, P1 = air minum $+1,8 \mathrm{ml}$ teh kombucha kadar 75\% pagi dan sore fermentasi 6 hari, $\mathrm{P} 2=$ air minum $1,8 \mathrm{ml}$ teh kombucha kadar $75 \%$ pagi dan sore fermentasi 9 hari, P3= air minum $1,8 \mathrm{ml}$ teh kombucha kadar $75 \%$ pagi dan sore fermentasi 12 hari. 
Seiring dengan penurunan kadar kolesterol dalam serum darah dari hasil analisis kadar HDL pada perlakuan pemberian teh kombucha kadar $75 \%$ yang difermentasi selama 6,9 dan 12 hari menunjukkan perbedaan yang nyata terhadap kontrol. Perlakuan pemberian teh kombucha kadar $75 \%$ fermentasi 6 dan 9 hari menunjukkan perbedaan yang tidak nyata, kemudian pada perlakuan pemberian teh kombucha kadar $75 \%$ fermentasi 6 dan 12 hari maupun 9 dan 12 hari menunjukkan perbedaan yang nyata seperti terlihat pada Tabel 1 dan Gambar 2.
Hasil analisis kadar LDL pada perlakuan pemberian teh kombucha kadar $75 \%$ yang difermentasi selama 6, 9 dan 12 hari menunjukkan perbedaan yang nyata terhadap kontrol. Perlakuan pemberian teh kombucha kadar $75 \%$ fermentasi 9 dan 12 hari menunjukkan perbedaan yang tidak nyata, kemudian pada perlakuan pemberian teh kombucha kadar $75 \%$ fermentasi 6 dan 9 hari maupun 6 dan 12 menunjukkan perbedaan yang nyata seperti tampak pada Tabel 1 dan Gambar 3.

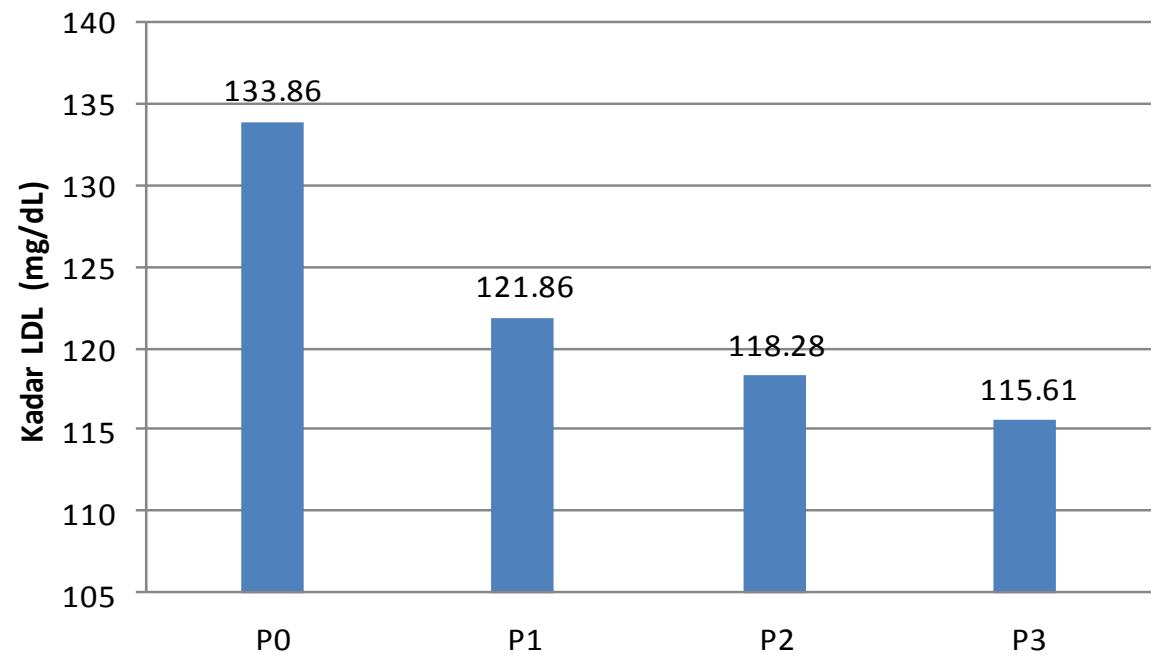

Gambar 3. Histogram rata-rata kadar LDL (mg/dL) pada setiap perlakuan

Keterangan :

P0 $=$ kontrol, tanpa tambahan teh kombucha kadar 75\%, P1 = air minum $+1,8 \mathrm{ml}$ teh kombucha kadar $75 \%$ pagi dan sore fermentasi 6 hari, $\mathrm{P} 2=$ air minum $1,8 \mathrm{ml}$ teh kombucha kadar $75 \%$ pagi dan sore fermentasi 9 hari, $\mathrm{P} 3=$ air minum $1,8 \mathrm{ml}$ teh kombucha kadar $75 \%$ pagi dan sore fermentasi 12 hari.

Penyakit pada arteria dapat terjadi dengan peningkatan kadar kolesterol LDL dan VLDL dalam darah (hiperkolesterol). Kenaikan kadar kolesterol ini dapat terjadi bila ada gangguan pembentukan kolesterol dalam hepar atau usus halus (Sherwood, 2001). Kadar kolesterol LDL yang tinggi akan memicu penimbunan kolesterol di sel pembuluh darah, yang menyebabkan munculnya aterosklerosis dan terbentuknya plak di dinding pembuluh darah (Libby \& Theroux, 2005). Aterosklerosis berhubungan dengan peningkatan LDL. Pengaruh peningkatan kadar LDL akan diikuti akumulasi ester kolesterol dalam makrofag sehingga kemudian makrofag disebut sebagai sel busa. Kadar LDL yang tinggi menyebabkan tingginya kadar LDL intimal. Selanjutnya LDL intimal akan mengalami oksidasi dan menarik monosit dari sirkulasi darah serta berubah secara fenotipik menjadi makrofag. Peningkatan LDL teroksidasi pada dinding arteri disertai dengan terbentuknya sel busa, akan berkembang menjadi lempeng lemak (Bankson et al., 1993). 


\section{SIMPULAN}

Hasil penelitian menunjukkan bahwa pemberian teh kombucha kadar $75 \%$ yang difermentasi selama 6,9 dan 12 hari dapat menaikkan kadar HDL, menurunkan kadar kolesterol dan kadar LDL serum darah tikus putih (Rattus norvegicus), sehingga dapat disimpulkan bahwa teh kombucha kadar $75 \%$ yang difermentasi selama 6, 9 dan 12 hari berpotensi digunakan sebagai suplemen untuk pencegahan risiko terhadap penyakit pembuluh darah dan jantung koroner.

\section{DAFTAR PUSTAKA}

Adriani, L., Mayasari, N., Angga and Kartasudjana, R. 2011. The effect of fermented Kombucha tea on HDL,LDL and Total Cholesterol levels in the duck bloods. Faculty of Animal Husbandry, Padjadjaran University, Bandung. Indonesia. Biotechnology in Animal Husbandry, Volume 27, No. 4. 1749-1755. 1 maret 2012.

Bankson, D.D. M. Kestin. and N. Rifai. 1993. Role of free radikal in cancer and atherosclerosis. Nutr. Support. 13:463477.

Devlin, M. 1992. Textbook of Biochemistry, with Clinical Corelations. Willeyliss. New York.

Haksa, K. 2010. Kadar kolesterol normal bukan jaminan terbebas dari risiko penyakit jantung koroner. 17 September 2010. Kompas.com. All rights reserved.

Libby, P. and P. Theroux. 2005. Pathophysiology of coronary artery disease. Circulation. 111:3481-3488

Linder, M.C. 1992. Biokimia Nutrisi dan Metabolisme, dengan Pemakaian secara klinis. Penerjemah Aminuddin Parakkasi. Cetakan ke 1. Penerbit Universitas Indonesia (UI-Press). Jakarta.

Mathews, K.C. and K. E. Van Holde. 1991. Biochemistry. The Benjamin/Cummings Co.Inc. New York.
Mattjik, A.A. dan I.M. Sumertajaya. 2006. Perancangan Percobaan dengan Aplikasi SAS dan Minitab. Ed. Ke-3. IPB-Press. Bogor.

Mayes, P.A. and K.M. Botham. 2003 ${ }^{\mathrm{a}}$. Lipid Storage \& Transport. Harper's Illustrated Biochemistry, $26^{\text {nd }}$ edition. Mc.Graw Hill, 205-217.

Mayes, P.A. and K.M. Botham. 2003 ${ }^{\mathrm{b}}$. Cholesterol Synthesis, Transport, and Excretion. Harper's Illustrated Biochemistry, $26^{\text {nd }}$ edition. Mc. Graw Hill, 219-227.

Naland, H. 2008. Kombucha; Teh dengan seribu khasiat. Agromedia Pustaka, Jakarta.

Poedjiadi, A. 1994. Dasar-dasar Biokimia. UI Press. Jakarta.

Pratiwi, A. Elfira, Aryawati, R. 2012. Pengaruh Waktu Fermentasi terhadap sifat fisik dan kimia pada pembuatan minuman kombucha dari Rumput Laut Sargassum sp. Maspari Journal. 2012. 4(1). 131-136.

Purwaning, A. 2010. Pengaruh kombucha Teh (Acetobacter xylinum) terhadap kadar kolesterol tikus putih jantan (Rattus norvegicus). Jurnal Department of Biology Universitas Muhammadiyah, Malang. Studentresearch.umn.ac.id/print/student_research_ 4178.html 4 Maret 2012

Rahayu, T. 2005. Kadar kolesterol darah tikus putih setelah pemberian cairan kombucha per oral Jurusan Pendidikan Biologi, FKIP Universitas Muhammadiyah, Surakarta. Jurnal Penelitian Sains dan Teknologi, Volume 6, No.2.

Sherwood, L. 2001. Human Phisiology: From Cells to Systems. A Division of Internasional Thomson Publishing Inc. All Right Reserved.

Winarni, D., Eva,N., Faqihuddin, A., Galih,H. dan Toumi, S. 2010. Pengaruh pemberian teh kombucha terhadap penurunan kadar kolesterol total dalam darah. Universitas Sebelas Maret Surakarta. Fk.uns.ac.id. 1 Maret 2012 